\title{
Mitochondrial Dysfunction in Diseases, Longevity, and Treatment Resistance: Tuning Mitochondria Function as a Therapeutic Strategy
}

\author{
Kazuo Tomita ${ }^{1, *}$, Yoshikazu Kuwahara ${ }^{1,2}$, Kento Igarashi ${ }^{1}$, Mehryar Habibi Roudkenar 1,3, \\ Amaneh Mohammadi Roushandeh ${ }^{1,3}$, Akihiro Kurimasa ${ }^{2}$ and Tomoaki Sato ${ }^{1}$ \\ 1 Department of Applied Pharmacology, Graduate School of Medical and Dental Sciences, Kagoshima \\ University, 8-35-1 Sakuragaoka, Kagoshima-City 890-8544, Kagoshima, Japan; \\ y-kuwahara@tohoku-mpu.ac.jp (Y.K.); knt-igrs@dent.kagoshima-u.ac.jp (K.I.); \\ roudkenar@gums.ac.ir (M.H.R.); mohammadi_roushandeh@gums.ac.ir (A.M.R.); \\ tomsato@dent.kagoshima-u.ac.jp (T.S.) \\ 2 Division of Radiation Biology and Medicine, Faculty of Medicine, Tohoku Medical and Pharmaceutical \\ University, 1-15-1 Fukumuro, Sendai-City 983-8536, Miyagi, Japan; kurimasa@tohoku-mpu.ac.jp \\ 3 Burn and Regenerative Medicine Research Center, Velayat Hospital, School of Medicine, Guilan University of \\ Medical Sciences, Parastar St., Rasht 41887-94755, Iran \\ * Correspondence: ktomita@dent.kagoshima-u.ac.jp; Tel.: +81-99-275-6162
}

Citation: Tomita, K.; Kuwahara, Y.; Igarashi, K.; Roudkenar, M.H.; Roushandeh, A.M.; Kurimasa, A.; Sato, T. Mitochondrial Dysfunction in Diseases, Longevity, and Treatment Resistance: Tuning Mitochondria Function as a Therapeutic Strategy. Genes 2021, 12, 1348. https:/ / doi.org/10.3390/genes12091348

Academic Editors: Angela Maria Serena Lezza, Vito Pesce and Guglielmina Chimienti

Received: 28 July 2021

Accepted: 26 August 2021

Published: 29 August 2021

Publisher's Note: MDPI stays neutral with regard to jurisdictional claims in published maps and institutional affiliations.

Copyright: (c) 2021 by the authors. Licensee MDPI, Basel, Switzerland. This article is an open access article distributed under the terms and conditions of the Creative Commons Attribution (CC BY) license (https:// creativecommons.org/licenses/by/ $4.0 /)$.
Abstract: Mitochondria are very important intracellular organelles because they have various functions. They produce ATP, are involved in cell signaling and cell death, and are a major source of reactive oxygen species (ROS). Mitochondria have their own DNA (mtDNA) and mutation of mtDNA or change the mtDNA copy numbers leads to disease, cancer chemo/radioresistance and aging including longevity. In this review, we discuss the mtDNA mutation, mitochondrial disease, longevity, and importance of mitochondrial dysfunction in cancer first. In the later part, we particularly focus on the role in cancer resistance and the mitochondrial condition such as mtDNA copy number, mitochondrial membrane potential, ROS levels, and ATP production. We suggest a therapeutic strategy employing mitochondrial transplantation (mtTP) for treatment-resistant cancer.

Keywords: mitochondria; mitochondrial DNA; clinically relevant radioresistant (CRR) cells; cancer radioresistance

\section{Introduction}

A major function of mitochondria is the production of Adenosine tri-phosphate (ATP). Mitochondria use pyruvic acid in the cytoplasm to efficiently produce ATP via the tricarboxylic acid (TCA) cycle and the electron transport chain (ETC). In recent years, it has become clear that mitochondria not only function as an ATP-producing organelle, but also as a signaling center in cell death such as apoptosis and ferroptosis [1-4]. Mitochondria have also been reported as a major site of reactive oxygen species (ROS) generation [5]. High concentrations of mitochondria-derived ROS are toxic but moderate concentrations have been shown to act as signaling molecules and play an important role in cellular functions, such as cell proliferation [5,6]. Mitochondria-derived ROS also regulate cancer cell growth [6-8]. Therefore, mitochondria are very important intracellular organelles that play key roles in normal physiological functions as well as pathophysiological functions. In this review, we discuss and highlight the importance and involvement of mitochondria in normal and disease conditions, specifically focusing on cancer chemoresistance and radioresistance (treatment resistance). We also describe the crucial role of mitochondria in cancer therapy. 
1.1. Association of Mitochondrial DNA (mtDNA) Mutations in Several Diseases, Longevity, and Radioresistance

Mitochondria have their own DNA (mtDNA). In eukaryotes, almost all the cells except red blood cells have mitochondria and mtDNA, and mtDNA is present in the hundreds to thousands per cell. It has been reported that the mtDNA is inherited maternally [9]. The human mtDNA genome encodes 13 genes, 22 tRNAs, and 2 rRNAs [10]. The 13 genes encoded by mtDNA are all core subunits of oxidative phosphorylation (OXPHOS). OXPHOS is a series of phosphorylation reactions that occur in mitochondria in conjugation with ETC, that is, ATP synthesis reaction (see detail in Section 1.3). It has been reported that mtDNA replication occurs independently of the cell cycle [11]. mtDNA is compacted or relaxed by the concentration of mitochondrial transcription factor (TFAM). When mtDNA is in a relaxed state, mtDNA forms replisome, which is composed of DNA polymerase Gamma (POL $\gamma$ ), mitochondrial DNA helicase (TWINKLE) and mitochondrial single-stranded DNA-binding protein (mtSSB), and replication occur [12,13]. The RNA primers for replication initiation are generated by mitochondrial RNA polymerase (POLRMT) and replication is proceeds. Moreover, mRNA and protein synthesis i.e., transcription and translation in mitochondria are also different from nuclear DNA. The codon of mtDNA is different from nuclear DNA and uses its own tRNA and ribosomal RNA [14]. Unlike nuclear DNA, mtDNA is not protected by histones and is susceptible to gene mutations. The implication of mtDNA mutations in specific diseases, especially mitochondrial diseases has been reported [15-18]. Mitochondrial disease exhibits various symptoms due to impaired mitochondrial function. Mitochondrial myopathy, encephalopathy, lactic acidosis, and stroke-like episodes (MELAS), myoclonic epilepsy and ragged red fibers (MERRF), chronic progressive external ophthalmoplegia (CPEO), and Leigh syndrome are examples of typical mitochondrial diseases [19]. MELAS is a serious illness with stroke-like symptoms and is diagnosed in early childhood or in the juvenile period [20]. Over 80\% of MELAS patients have A3243G mutation and about $10 \%$ of MELAS patients have T3271C mutation. These mutations are on the tRNA ${ }^{\mathrm{Leu}(\mathrm{UUR})}$. This mutation leads to destabilization of tRNA and leads to reduction of the production of oxidative phosphorylation (OXPHOS) proteins, which produce ATP [21]. MERRF is characterized by myoclonic epilepsy and develops at a relatively old age [22]. About $80 \%$ of MERRF patients have A8344G mutation. The symptoms of this disease are reported to be associated with mutations in complexes of NADH-CoQ reductase and cytochrome C-oxidase (COX) [23]. CPEO is characterized by visual muscles' myopathy and ptosis, pigmentary degeneration of retina, and dysfunction of central nervous system [24]. CPEO is one of the most common mtDNA diseases in adults and caused by point mutation [25] or sporadic large-scale deletions [26,27]. Leigh syndrome is an infantile sub-acute necrotizing encephalopathy. It is a progressive neurodegenerative disease [28]. In this syndrome, it is found that the complex I of ETC is missing [28]. Currently, there is no cure for any mitochondrial disease, and most are treated symptomatically. A number of studies also report that mtDNA mutations have been implicated in other diseases such as deafness [29-31], diabetes mellitus [29], Alzheimer's disease [31], Parkinson's disease [32], hypertension [33], prostate cancer [34], and exercise intolerance (due to a mutation in the cytochrome $b$ gene) [35]. Figure 1 lists the mtDNA mutations that cause various diseases, as well as mutations that affect longevity or radioresistance [36-47]. 


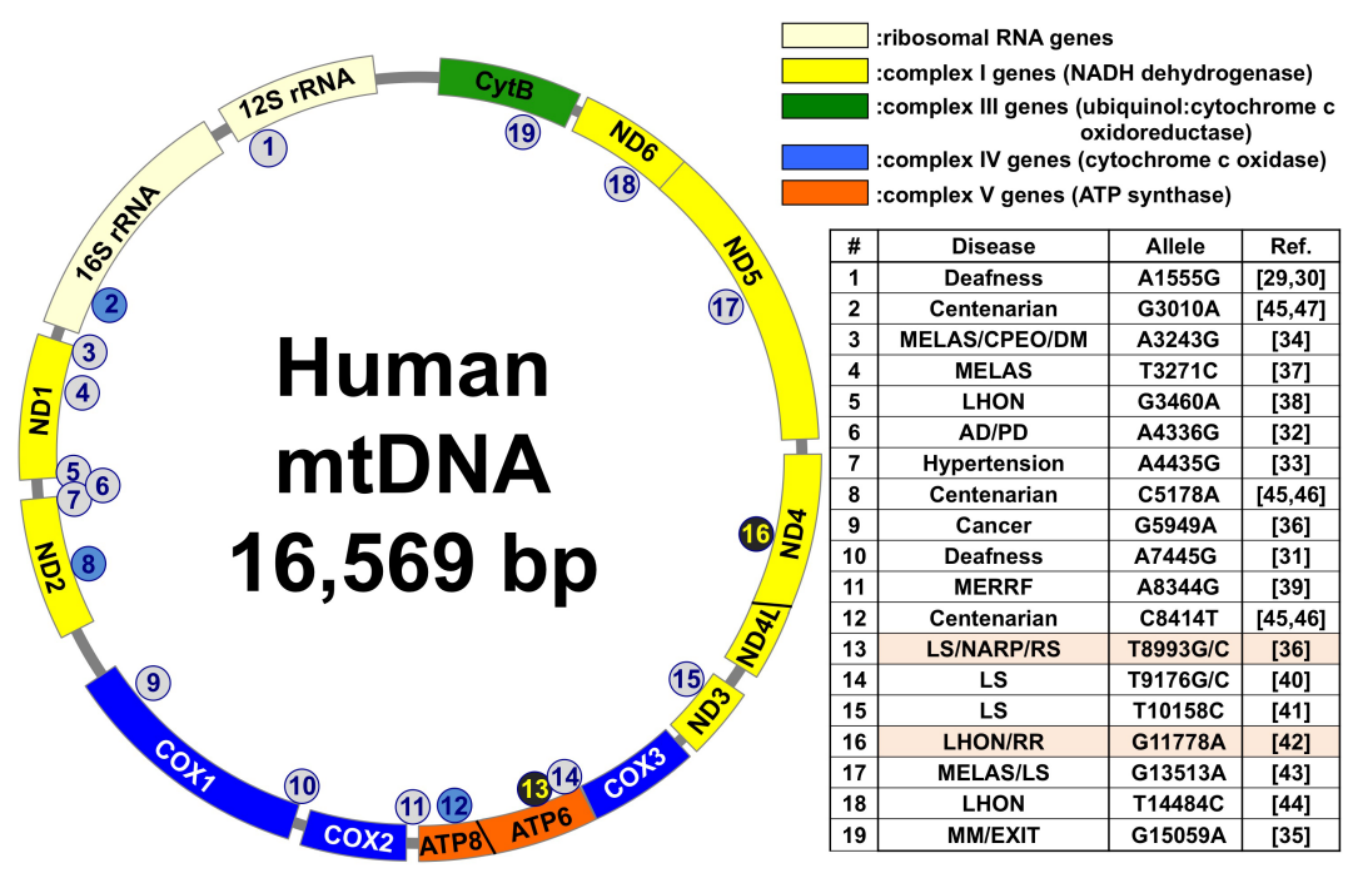

Figure 1. Mitochondrial DNA (mtDNA) mutations that cause various diseases, as well as mtDNA mutations that affect longevity or radioresistance. Centenarian: a person over 100 years old; MELAS: mitochondrial myopathy, encephalopathy, lactic acidosis, and stroke-like episodes; CPEO: chronic progressive external ophthalmoplegia; DM: diabetes mellitus; LHON: Leber's hereditary optic neuropathy; AD/PD: Alzheimer's and Parkinson's diseases; MERRF: myoclonic epilepsy and ragged red fibers; LS: Leigh syndrome; NARP: neuropathy, ataxia, and retinitis pigmentosa; RS: radiosensitive; RR: radioresistance; MM: mitochondrial myopathies; EXIT: exercise intolerance.

Several studies have reported that mtDNA mutations play various roles in aging [48-50]. Furthermore, it has been shown that various individual mtDNA mutations are present in centenarians [45-47]. For example, A5178C mutation, which was found in centenarians, changes the 237th amino acid of ND2 from Leucine to Methionine. Methionine residue in the protein has been reported to have a protective effect on mitochondria against oxidative damage and therefore this mutation is suggested to contribute the longevity at least in part [51]. A5178C mutation has also been reported to protect from myocardial infarction because of the anti-oxidative effect [51]. Moreover, it has been found that there is a mutation (referred to as the "common deletion") that harbors a 4977 base pair deletion of mtDNA in the D-loop and this deletion increases with age [52]. This deletion has also been implicated in the prognosis of breast cancer [53].

A mtDNA mutation (G11778A) has been reported to be implicated in radioresistance [42]. The G11778A mutation is able to repair double strand breaks and leads to short term radiation survival [42]. On the other hand, T8993G mutation has been reported to show radiosensitivity. This mutation is located in the ATP6 gene and decreases ATP synthase, which produce ATP. This mutation has been reported to increase mitochondrial ROS production [44] and show radiosensitivity [54].

\section{2. mtDNA Copy Number and Its Roles in Disease, Longevity, and Treatment Resistance}

There are multiple copies of mtDNA in mitochondria. Of note, aged populations have a lower mtDNA copy number in blood $[55,56]$ and exhibit mtDNA heteroplasmy (the presence of more than one type of organelle genome) $[57,58]$. These results show that mtDNA quantity and quality decrease with age. On the other hand, in the Amami region, which is one of the highest proportions of centenarians, it has been reported that the mtDNA copy number from blood of three groups (under 70, 70-90, over 90 years old) does not decrease with age [59]. In addition, the mtDNA mutation rate did not increase 
with age. These results indicate that mtDNA quality control plays an important role in longevity.

There are several reports investigating the relationship between mtDNA copy number and cancer. It has been reported that an increase in mtDNA copy number promotes colorectal cancer progression [60]. Additionally, it has been reported that an increase in mtDNA copy number was a risk in breast cancer, pancreatic tumor, lung cancer, lymphomas and skin cancer [61-66]. On the other hand, it has been reported that an increase in mtDNA copy number was protective in cancer [67]. In addition, according to findings from the Cancer Genome Atlas project, some cancers have less mtDNA content compared with normal tissue near the tumor [68]. Furthermore, in colorectal cancer, the risk of carcinoma development is associated with lower amount of mtDNA [69]. King et al. [70] established cultured cell lines, which are referred to as " $\rho^{0}$ cells" that lack mtDNA. It is noteworthy that $\rho^{0}$ cells show different behaviors compared to their parental cells. For example, $\rho^{0}$ cells from SK-Hep1 and SH-SY 5Y cells show resistance to oxidative stress [71,72]. In contrast, $\rho^{0}$ cells from yeast and teratocarcinoma cells show sensitivity to oxidative stress [73,74]. We previously showed that $\rho^{0}$ cells are more sensitive to hydrogen peroxide $\left(\mathrm{H}_{2} \mathrm{O}_{2}\right)$, which is a well-characterized ROS [75]. These findings indicate that there are relationships among mtDNA aging, cancer progression and treatment resistance. However, there is a discrepancy in the relationship between mtDNA depletion and oxidative tolerance. Therefore, we think it is very important to clarify this relationship and to investigate the need for functional mitochondria in cancer cells.

\subsection{ATP Synthesis, ROS Production, and Mitochondrial Membrane Potential ( $\triangle \Psi m)$ in Cancer and Cell Death}

Energy production is the main function of mitochondria. Mitochondria produce ATP by OXPHOS. The OXPHOS system is composed of the ETC and ATP synthase. The ETC is composed of complexes I, II, III and IV. ETC transports electrons from complex I to complex IV. During electron transport, a proton gradient is formed over the inner mitochondrial membrane and protons were transported into the mitochondria matrix via ATP synthase. Before the ETC, glucose is metabolized to pyruvate by the glycolysis in the cytosol. Pyruvate then enters into mitochondria by pyruvate dehydrogenase and resulting in mitochondrial acetyl-CoA, nicotinamide adenine nucleotide (NADH) $+\mathrm{H}$, and $\mathrm{CO}_{2}$. Acetyl-CoA then enters the tricarboxylic acid (TCA) cycle, which generates further $\mathrm{NADH}+\mathrm{H}$. These $\mathrm{NADH}+\mathrm{H}$ and $\mathrm{FADH}_{2}$ from beta-oxidation give an electron to NADH dehydrogenase in complex I and proceed ETC. The ETC system is prone to electron leakage, which generates ROS, i.e., superoxide [76] and $\mathrm{H}_{2} \mathrm{O}_{2}$ [77]. This leakage also induces lipid peroxidation in mitochondrial membranes, which alters the $\Delta \Psi \mathrm{m}[78,79]$.

It has been reported that cancer cells produce ATP via glycolysis rather than OXPHOS even under aerobic conditions $[80,81]$, which leads to low $\Delta \Psi \mathrm{m}$, resulting in resistance to cell death [82]. It has been proven that $\Delta \Psi \mathrm{m}$ is involved in cell death [83]. When the mitochondrial membrane permeable transition pore $(\mathrm{mPTP})$ is opened by a stimulus such as stress, ions and small molecules pass through the membrane and the $\Delta \Psi \mathrm{m}$ disappears.

\section{Mitochondria Transplantation (mtTP) as a Novel Therapeutic Strategy}

It has been shown that mitochondria can be transferred both artificially and under normal physiological state. We can transfer mitochondria as a "cybrid" [70] or treated isolated mitochondria directly into the cells or tissues $[84,85]$. We can also transfer mitochondria by co-culture cells as a normal physiological state [86]. Mitochondria transfer from one cell to another cell occurs especially when the mitochondria are injured [87]. Therefore, the mitochondrial transplantation from healthy cells to abnormal cells is thought to be a novel and attractive therapeutic concept. It has been reported that mitochondria and/or organelles transfer between cells through tunneling nanotubes [88]. After the report, replacement of damaged mitochondria with healthy mitochondria has been developed in order to overcome mitochondrial diseases and mitochondria dysfunctions [89-97]. It has been shown that mtTP rescues ischemia reperfusion-induced damage and protects the 
brain from apoptosis [93]. Current clinical and preclinical studies utilizing mtTP have been conducted or are in progress for the treatment of heart ischemia, brain ischemia, sepsis, cancer, acute kidney injury, and theoretically for any disorders in which mitochondria are damaged and disrupted $[85,93,98,99]$.

One of the examples of mtTP is mitochondria donation between eggs in fertility treatment. This is a method used in in vitro fertilization called "pronuclear transfer". This procedure uses a donor egg that has healthy mitochondria. The fertilized donor eggs were enucleated and the nucleus from the mother's egg, which is also fertilized, was transplanted. This provides the fertilized egg with healthy mitochondria and nuclear DNA from the parent. The embryo is then returned to the mother's uterus and a healthy baby is born. The United Kingdom passed the first legislation in 2012 to allow the use of mtTP technology on the eggs and fertilized eggs of patients with mitochondrial diseases [100]. In addition, children who have undergone mtTP have already been born [101].

We have demonstrated that mitochondria from a non-cancer cell line can be transplanted into cancer cell lines that lack mtDNA ( $\rho^{0}$ cells) [94]. This mitochondrial transplantation has been checked using MitoTracker ${ }^{\mathrm{TM}}$, which can stain mitochondria, and confirmed that the healthy stained mitochondria from fibroblast cells have certainly transplanted into $\rho 0$ cells. Recently, in a clinical trial, it has been shown that mtTP leads to cardio protection [102]. Moreover, in the breast cancer cell line MCF-7, mtTP induces a decrease in mitochondrial ROS and superoxides via stimulating both superoxide dismutase 2 and catalase expression. Furthermore, mtTP inhibits MCF-7 cell proliferation, reduces cellular oxidative stress, and suppresses drug resistance [103]. It has been reported that $\mathrm{mtTP} \rho^{0}$ cells have decreased intracellular $\mathrm{Fe}^{2+}$ levels and downregulation of aquaporins. Since aquaporins regulate $\mathrm{H}_{2} \mathrm{O}_{2}$ permeability, these cells exhibit $\mathrm{H}_{2} \mathrm{O}_{2}$ resistance compared with the non-mtTP $\rho^{0}$ cells [96]. Thus, mtTP may enhance mitochondrial function that will allow for the rescue of cells and restoration of normal function. Taken together, these results indicate that mtTP may be an upcoming effective therapeutic option. Therefore, $\mathrm{mtTP}$ is a very promising technique, which may be applicable for the treatment of many diseases including cancer. However, mtTP is only in the beginning stages of development, so further investigation will be needed to address various technical and ethical issues. Table 1 shows the preclinical and clinical studies about mitochondrial transplantation.

Table 1. Preclinical and clinical studies about mitochondrial transplantation.

\begin{tabular}{|c|c|c|c|c|}
\hline Donor & Recipient & Disease & Result & Reference \\
\hline Rectus Abdominis & Heart & $\begin{array}{l}\text { Heart ischemia } \\
\text { reperfusion }\end{array}$ & $\begin{array}{l}\text { Cardiac function } \\
\text { improved }\end{array}$ & {$[85,98]$} \\
\hline Granular cells & Oocyte & Infertility & Normal babies were born & [101] \\
\hline Astrocytes & Neuron & Ischemic damage & Recover ATP production & [104] \\
\hline $\begin{array}{l}\text { HeLa cells (cervical } \\
\text { cancer cell line) }\end{array}$ & AD model mice & Alzheimer disease & $\begin{array}{c}\text { Cognitive defect and } \\
\text { gliosis were ameliorated }\end{array}$ & [105] \\
\hline $\begin{array}{l}\text { Cybrids from PC-12 cells } \\
\text { and human osteosarcoma }\end{array}$ & Brain & $\begin{array}{l}\text { 6-OHDA induced PD } \\
\text { model }\end{array}$ & $\begin{array}{l}\text { Improve motor function } \\
\text { and mitochondrial } \\
\text { function }\end{array}$ & [106] \\
\hline $\begin{array}{l}\text { BHK-21 cell (kidney cell } \\
\text { line) }\end{array}$ & Sciatic nerve & Sciatic nerve crush & $\begin{array}{c}\text { Injured sciatic nerve } \\
\text { improved }\end{array}$ & [107] \\
\hline Oocyte cytoplasm & Oocyte & Infertility & Increase pregnancy & [108] \\
\hline Mesenchymal stem cells & Brain & $\begin{array}{l}\text { Rat brain ischemia } \\
\text { reperfusion }\end{array}$ & $\begin{array}{l}\text { Protect from apoptosis } \\
\text { Restores motor function } \\
\text { Prohibitin } 2 \text { enhancement }\end{array}$ & [94] \\
\hline WI-38 (fibroblast cell line) & $\rho^{0}$ cells (HeLa, SAS) & mtDNA deficient & $\begin{array}{l}\text { Survive without } \\
\text { pyruvate and uridine }\end{array}$ & [97] \\
\hline $\begin{array}{l}\text { MLO-Y4 cell (osteocyte } \\
\text { cell line) }\end{array}$ & $\rho^{0}$ cells (MLO-Y4) & mtDNA deficient & Increase ATP production & [109] \\
\hline
\end{tabular}




\section{Involvement of Mitochondrial Dysfunction in Treatment-Resistant Cancer Cells}

In order to investigate the molecular mechanism(s) of radioresistance in cancer cells, we established radioresistant cell lines by step-wise fractionated X-ray exposure [110-113]. In this procedure, the cells are exposed to X-rays ( $2 \mathrm{~Gy} /$ day) for at least a month, which induces radiation resistance. The established cells were referred to as "clinically relevant radioresistant (CRR)" cells [110]. The morphology of the CRR cells was different from their parental cells and they appeared to be more tightly bound to each other than their parental cells (Figure 2). Moreover, CRR cells exhibit low levels of DNA double strand breaks after ionizing radiation (IR) exposure [110]. In addition, the CRR cells are not only IR resistant but also $\mathrm{H}_{2} \mathrm{O}_{2}$ resistant despite low catalase enzyme activity. Interestingly, the expression of other antioxidative enzyme genes does not seem to be upregulated in CRR cells [114]. CRR cells also exhibit lipid peroxidation resistance upon $\mathrm{H}_{2} \mathrm{O}_{2}$ treatment. Lipid peroxidation normally leads to cell death and this lipid peroxidation resistance was due to a decrease in the expression level of lipoxygenase (ALOX). Administration of oxidized lipids to cancer cells increases cell death and an inhibitor of ALOX decreases lipid peroxidation [114]. Moreover, it has been reported that ALOX targets mitochondria under oxidative stress. For example, when ALOX was administrated into isolated mitochondria, cytochrome c release and ROS generation were observed [115]. Furthermore, it has been reported that ALOX expression was enhanced in CRR cells, and overexpression of ALOX12 enhances ROS generation and amount of HNE, which is one of the lipid peroxidation by-products [116]. These results indicate that the CRR cells inhibit ferroptosis and show resistance from oxidative stress via decreasing mitochondrial function. The characteristics of CRR cells known to date are summarized in Table 2. These results show that plasma membrane status and lipid peroxidation enzyme activity are very important in oxidative stress resistance.

Table 2. Characteristics of clinically relevant radioresistant (CRR) cells.

\begin{tabular}{ccc}
\hline \multicolumn{2}{c}{ CRR Characteristics } & References \\
\hline Morphology & Tight binding & This review, [116] \\
Irradiation & Resistant & {$[111,117]$} \\
$\mathrm{H}_{2} \mathrm{O}_{2}$ & Resistant & {$[114]$} \\
Docetaxel & Resistant & {$[118]$} \\
DNA DSB & Low & {$[112]$} \\
$\Delta \Psi \mathrm{m}$ & Low & {$[118]$} \\
Superoxide & Low & {$[114]$} \\
Hydroxyl radical & Low & {$[114]$} \\
Lipid peroxidation & Low & {$[114]$} \\
mtDNA copy number & Low & {$[114]$} \\
ATP production & Low & {$[114]$} \\
Fe ${ }^{2+}$ amount & Low & {$[119]$} \\
AQP8 gene expression & Low & {$[114]$} \\
ALOX gene expression & Low & {$[114]$} \\
GBP1 gene expression & High & {$[120]$} \\
miR-7-5p expression & High & {$[119]$} \\
\hline
\end{tabular}




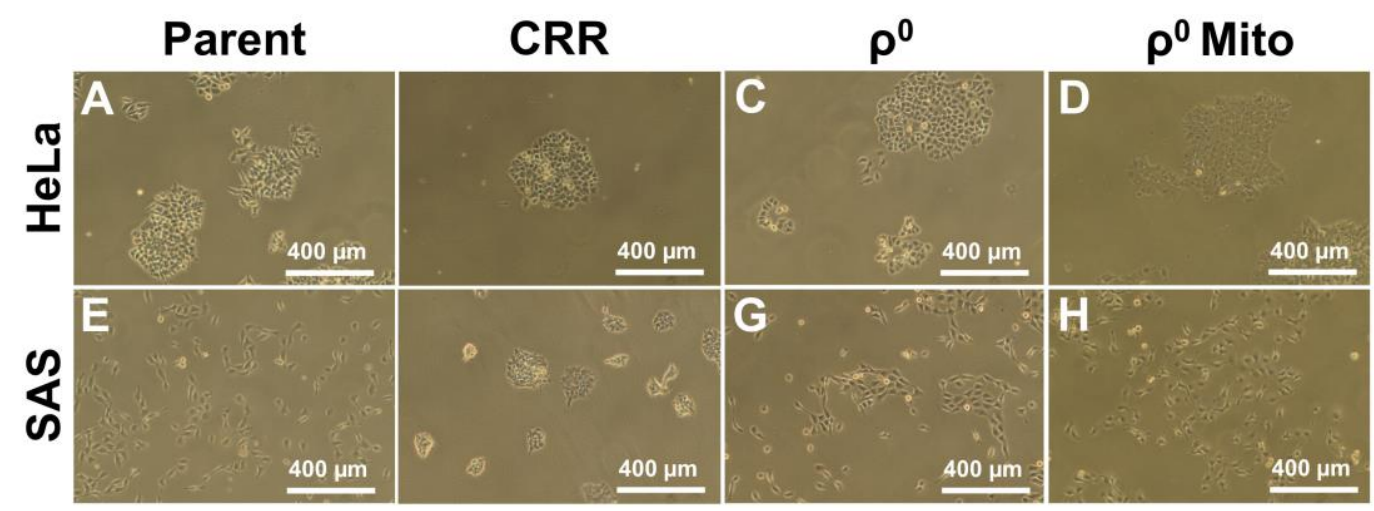

Figure 2. Morphology of CRR cells, $\rho^{0}$ cells, $\rho^{0}$ cells harboring transferred mitochondria, and parental cells. (A): HeLa parent cells, (B): HeLa CRR cells, (C): HeLa $\rho^{0}$ cells, (D): HeLa $\rho^{0}$ Mito cells, (E): SAS parent cells, (F): SAS CRR cells, (G): SAS $\rho^{0}$ cells, $(\mathbf{H})$ : SAS $\rho^{0}$ Mito cells.

There are additional CRR cell characteristics that may contribute to their treatment resistant phenotype. For example, CRR cells have both low $\Delta \Psi \mathrm{m}$ and superoxide production [118]. Furthermore, CRR cells are resistant not only to IR but also to docetaxel, which can increase the level of mitochondrial ROS production [118]. A DNA array experiment showed that CRR cells express higher levels of guanine nucleotide-binding protein 1 (GBP1) compared to parental cells and when GBP1 is knocked down by siRNA, CRR cells lose their radioresistance [120]. Recently, it has been reported that knockdown of GBP1 results in impaired mitochondrial respiratory function [121]. Treatment with everolimus, an mTOR inhibitor, abolishes the IR resistance properties of CRR cells [110]. In addition, the autophagy inducer rapamycin increases the radiosensitivity of CRR cells and the autophagy inhibitor 3-methyladenine induces radioresistance in parental cells [122]. Furthermore, an mTOR inhibitor affects mitochondria dynamics [123]. These results show strong relationships between radioresistance, autophagy, and mitochondria. There is also a correlation between radioresistance and mtDNA copy number. For example, mtDNA copy number was decreased in CRR cells compared to parental cells [112]. Furthermore, CRR cells had low ATP production, low ROS levels, low $\Delta \Psi \mathrm{m}$, and low aquaporin 8 gene expression, of which the latter is expressed in both the plasma and mitochondrial membranes $[113,114,124]$. MicroRNA array analysis revealed that CRR cells had higher miR-7-5p expression levels compared to parental cells [119]. Candidate target genes of miR-7-5p are summarized in Table 3. One of the target genes is SLC25A37 (mitoferrin), an iron transporter in mitochondria. When this gene was knocked down by siRNA, radioresistance was observed in parental cells [119]. Moreover, mitochondrial $\mathrm{Fe}^{2+}$ levels were significantly decreased in CRR cells [119]. Mitoferrin is a mitochondrial iron importer that synthesizes mitochondrial heme and iron-sulfur clusters. These results suggest that mitoferrin have an important role in CRR cell characteristics. Recently, inhibition of mir-7-5p decreased intracellular and mitochondrial ROS, enhanced JC-1 signal, which is an indicator of $\Delta \Psi \mathrm{m}$, downregulated the ferritin gene expression, and enhanced the ALOX12 gene expression [116]. In contrast, $\rho^{0}$ cells show high $\mathrm{Fe}^{2+}$ amount, high lipid peroxidation, and low ALOX expression. These factors are different (opposite) from CRR cells and $\rho^{0}$ cells considered to be sensitive to the oxidative stress. Interestingly, CRR cells lose their radioresistance when irradiation is terminated, and the cells are cultured for more than six months [119]. This result strongly suggests that this phenotype is reversible and radioresistance induced by irradiation also has the potential for reversibility. Therefore, further investigation of CRR cells is very important to eradicate cancer. Recently, it has been reported that an Italian group has established a cell line in rhabdomyosarcoma, also named clinically relevant radioresistant cells [125]. They establish these cells by irradiating $6 \mathrm{~Gy} \times 6$ times not $2 \mathrm{~Gy} /$ day, but show radioresistance. These cells have been reported to 
produce less mitochondrial superoxide. Taken together, these data show that mitochondria play key roles in cancer therapy and resistance to treatment.

Table 3. miR-7-5p target genes.

\begin{tabular}{cccc}
\hline Localization & \multicolumn{3}{c}{ Gene Name } \\
\hline \multirow{2}{*}{ Plasma membrane } & ATP2B2 & FLRT2 & SEMA4C \\
\cline { 2 - 4 } & SEAMA6D & TMEM65 & VSTM4 \\
\hline \multirow{2}{*}{ Cytoplasm } & AKT3 & MAPK4 & PTPMT1 \\
\cline { 2 - 4 } & CRLS1 & NDFUA4 & SLC25A37 \\
\cline { 2 - 4 } & SLC25A15 & SLC25A16 & VDAC1 \\
\hline ER & TIMM50 & TMEM65 & - \\
\hline Lysosome & SERP1 & - & - \\
\hline Golgi apparatus & BLOC1S4 & - & GOLGB1 \\
\hline
\end{tabular}

ATP2B2: ATPase plasma membrane $\mathrm{Ca}^{2+}$ transporting 2; FLRT2: Fibronectin Leucine Rich Transmembrane Protein 2; SEMA4C: Semaphorin 4C; SEAMA6D: Semaphorin 6D; TMEM65: Transmembrane Protein 65; VSTM4: V-Set And Transmembrane Domain Containing 4; AKT3: AKT Serine/Threonine Kinase 3; MAPK4: MitogenActivated Protein Kinase 4; CRLS1: Cardiolipin Synthase 1; NDFUA4: NADH dehydrogenase (ubiquinone) 1 Alpha subcomplex subunit 4; PTPMT1: Protein Tyrosine Phosphatase Mitochondrial 1; SLC25A15: Mitochondrial ornithine transporter 1; SLC25A16: Graves disease carrier protein; SLC25A37: Mitoferrin-1; TIMM50: Translocase Of Inner Mitochondrial Membrane 50; TMEM65: Transmembrane protein 65; VDAC1: Voltage-dependent anionselective channel protein 1; SERP1: Stress Associated Endoplasmic Reticulum Protein 1; BLOC1S4: Biogenesis Of Lysosomal Organelles Complex 1 Subunit 4; GLG1: Golgi Glycoprotein 1; GOLGB1: Golgin B1.

\section{Conclusions and Future Perspectives}

mtDNA mutations and mtDNA copy number are important not only for health, mitochondrial diseases, and aging but also for cancer radioresistance. Other mitochondrial parameters such as ATP production, $\triangle \Psi \mathrm{m}$, and ROS production are also involved in radioresistance. $\mathrm{mtTP}$ is now ready for clinical evaluation and this technology may be a promising therapeutic strategy for a variety of diseases with mitochondrial dysfunctions such as mitochondria diseases, myocardial infarction, acute kidney injury, aging, and cancer. To apply this technology, further investigation addressing various ethical and technical issues will be required. Additionally, a better understanding of the underlying mechanism of cancer cell resistance particularly clarifying the role of mitochondria in this process would lead to the development of more effective therapeutic strategies for cancer. Overall, in cancer cells it may be possible to fine-tune mitochondria function so that radioresistance might be overcome (summary in Figure 3). However, further investigation including animal studies and clinical trials are required in order to determine if altering mitochondrial function can confer radiosensitivity to cancer cells. 


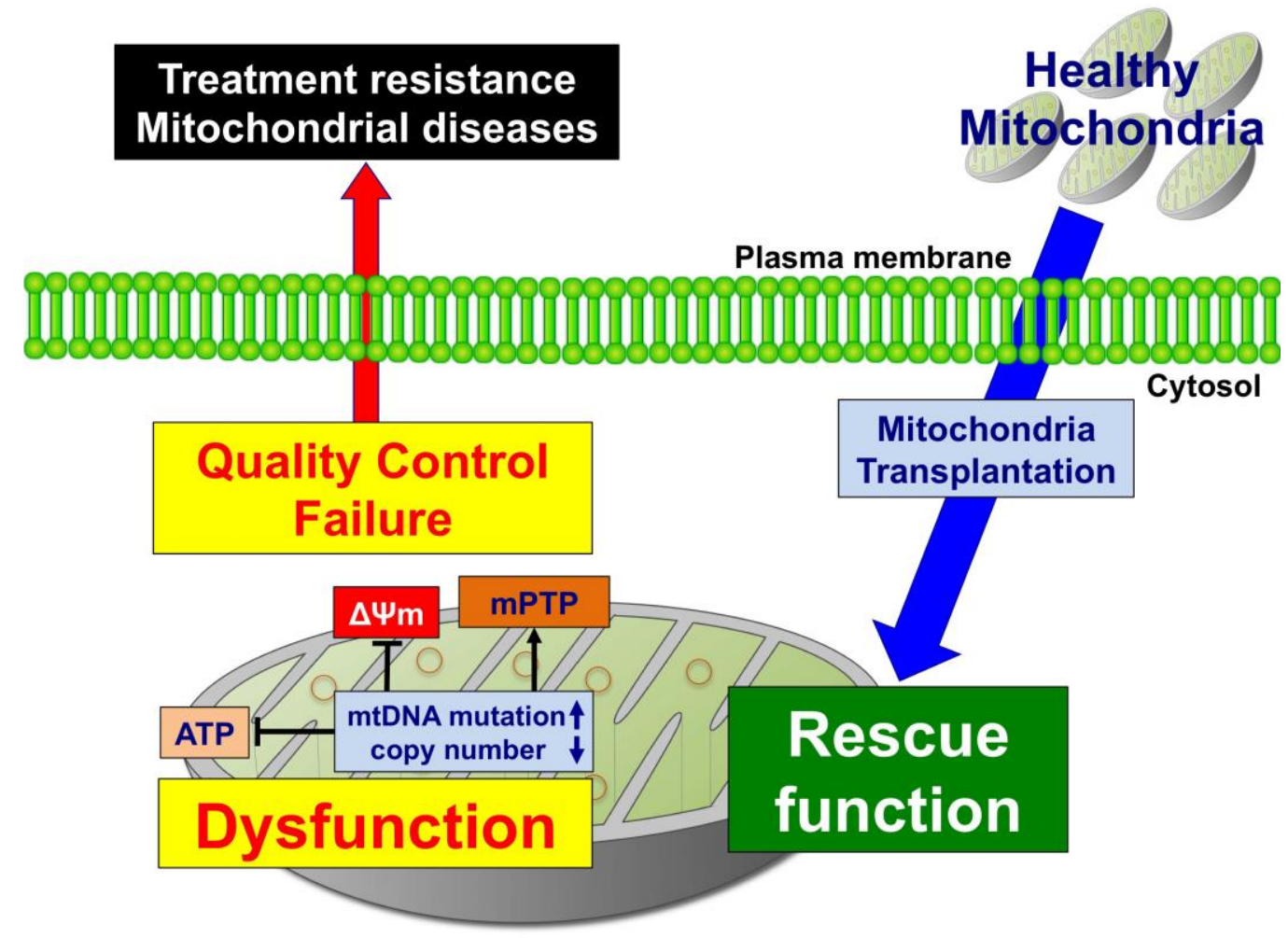

Figure 3. Mitochondria transplantation $(\mathrm{mtTP})$ is a candidate strategy designed to rescue mitochondrial quality control failure. Mitochondrial dysfunction induced by mtDNA mutation or a decrease in mtDNA copy number leads to a decrease in ATP production, a decrease in mitochondrial membrane potential $(\Delta \Psi \mathrm{m})$, and opening of the mitochondrial membrane permeable transition pore (mPTP). This mitochondrial quality control failure induces treatment resistance and mitochondrial disease. Mitochondrial quality control failure may be rescued by transplantation of healthy mitochondria.

Author Contributions: K.T.; Y.K.; T.S.; writing—original draft preparation, K.I.; M.H.R.; A.M.R. A.K.; writing - review and editing, supervision, K.T.; T.S.; funding acquisition, K.T. All authors contributed to the final critical review of the manuscript. All authors have read and agreed to the published version of the manuscript.

Funding: This research was funded by JSPS KAKENHI, grant number 19K10138.

Institutional Review Board Statement: Not applicable.

Informed Consent Statement: Not applicable.

Acknowledgments: The authors would like to thank Cambridge English Correction Service for the English language review.

Conflicts of Interest: The authors declare no conflict of interest.

\section{References}

1. Gupta, S. Molecular signaling in death receptor and mitochondrial pathways of apoptosis (Review). Int. J. Oncol. 2003, 22, 15-20. [CrossRef]

2. Green, D.R.; Kroemer, G. The Pathophysiology of Mitochondrial Cell Death. Science 2004, 305, 626-629. [CrossRef]

3. Elmore, S. Apoptosis: A Review of Programmed Cell Death. Toxicol. Pathol. 2007, 35, 495-516. [CrossRef] [PubMed]

4. Gao, M.; Yi, J.; Zhu, J.; Minikes, A.M.; Monian, P.; Thompson, C.B.; Jiang, X. Role of Mitochondria in Ferroptosis. Mol. Cell. 2019, 73, 354-363. [CrossRef]

5. Ogura, A.; Oowada, S.; Kon, Y.; Hirayama, A.; Yasui, H.; Meike, S.; Kobayashi, S.; Kuwabara, M.; Inanami, O. Redox regulation in radiation-induced cytochrome c release from mitochondria of human lung carcinoma A549 cells. Cancer Lett. 2009, $277,64-71$. [CrossRef]

6. Forkink, M.; Smeitink, J.A.; Brock, R.; Willems, P.H.; Koopman, W.J. Detection and manipulation of mitochondrial reactive oxygen species in mammalian cells. Biochim. Biophys. Acta 2010, 1797, 1034-1044. [CrossRef] 
7. Singh, K.K. Mitochondrial dysfunction is a common phenotype in aging and cancer. Ann. N. Y. Acad. Sci. 2004, 1019, $260-264$. [CrossRef] [PubMed]

8. Idelchik, M.D.P.S.; Begley, U.; Begley, T.J.; Melendez, J.A. Mitochondrial ROS control of cancer. Semin. Cancer Biol. 2017, 47, 57-66. [CrossRef] [PubMed]

9. Giles, R.E.; Blanc, H.; Cann, H.M.; Wallace, D.C. Maternal inheritance of human mitochondrial DNA. Proc. Natl. Acad. Sci. USA 1980, 77, 6715-6719. [CrossRef] [PubMed]

10. Anderson, S.; Bankier, A.T.; Barrell, B.G.; de Bruijn, M.H.; Coulson, A.R.; Drouin, J.; Eperon, I.C.; Nierlich, D.P.; Roe, B.A.; Sanger, F.; et al. Sequence and organization of the human mitochondrial genome. Nature 1981, 290, 457-465. [CrossRef]

11. Bogenhagen, D.; Clayton, D.A. Mouse L cell mitochondrial DNA molecules are selected randomly for replication throughout the cell cycle. Cell 1977, 11, 719-727. [CrossRef]

12. Korhonen, J.A.; Pham, X.H.; Pellegrini, M.; Falkenberg, M. Reconstitution of a minimal mtDNA replisome in vitro. EMBO J. 2004, 23, 2423-2429. [CrossRef]

13. Wanrooij, S.; Falkenberg, M. The human mitochondrial replication fork in health and disease. Biochim. Biophys. Acta Bioenerg. 2010, 1797, 1378-1388. [CrossRef]

14. Clayton, D.A. Transcription and replication of mitochondrial DNA. Hum. Reprod. 2000, 15 (Suppl. 2), 11-17. [CrossRef]

15. Wallace, D.C. A Mitochondrial Paradigm of Metabolic and Degenerative Diseases, Aging, and Cancer: A Dawn for Evolutionary Medicine. Ann. Rev. Genet. 2005, 39, 359-407. [CrossRef] [PubMed]

16. Schon, E.A.; DiMauro, S.; Hirano, M. Human mitochondrial DNA: Roles of inherited and somatic mutations. Nat. Rev. Genet. 2012, 13, 878-890. [CrossRef] [PubMed]

17. Taylor, R.W.; Turnbull, D.M. Mitochondrial DNA mutations in human disease. Nat. Rev. Genet. 2005, 6, 389-402. [CrossRef] [PubMed]

18. Tuppen, H.A.; Blakely, E.L.; Turnbull, D.M.; Taylor, R.W. Mitochondrial DNA mutations and human disease. Biochim. Biophys. Acta 2010, 1797, 113-128. [CrossRef]

19. Suomalainen, A.; Battersby, B.J. Mitochondrial diseases: The contribution of organelle stress responses to pathology. Nat. Rev. Mol. Cell Biol. 2018, 19, 77-92. [CrossRef]

20. Kobayashi, Y.; Momoi, M.Y.; Tominaga, K.; Shimoizumi, H.; Nihei, K.; Yanagisawa, M.; Kagawa, Y.; Ohta, S. Respirationdeficient cells are caused by a single point mutation in the mitochondrial tRNA-Leu (UUR) gene in mitochondrial myopathy, encephalopathy, lactic acidosis, and strokelike episodes (MELAS). Am. J. Hum. Genet. 1991, 49, 590-599.

21. Lorenzoni, P.J.; Werneck, L.C.; Kay, C.S.; Silvado, C.E.; Scola, R.H. When should MELAS (Mitochondrial myopathy, Encephalopathy, Lactic Aci- dosis, and Stroke-like episodes) be the diagnosis? Arq. Neuro-Psiquiatr. 2015, 73, 959-967. [CrossRef]

22. Dimauro, S. Mitochondrial diseases. Biochim. Biophys. Acta 2004, 1658, 80-88. [CrossRef] [PubMed]

23. Lorenzoni, P.J.; Scola, R.H.; Kay, C.S.; Silvado, C.E.; Werneck, L.C. When should MERRF (myoclonus epilepsy associated with ragged-red fibers) be the diagnosis? Arq. Neuro-Psiquiatr. 2014, 72, 803-811. [CrossRef] [PubMed]

24. Kabunga, P.; Lau, A.K.; Phan, K.; Puranik, R.; Liang, C.; Davis, R.L.; Sue, C.M.; Sy, R.W. Systematic review of cardiac electrical disease in Kearns-Sayre syndrome and mitochondrial cytopathy. Int. J. Cardiol. 2015, 181, 303-310. [CrossRef] [PubMed]

25. Moraes, C.T.; Ciacci, F.; Silvestri, G.; Shanske, S.; Sciacco, M.; Hirano, M.; Schon, E.A.; Bonilla, E.; DiMauro, S. Atypical clinical presentations associated with the MELAS mutation at position 3243 of human mitochondrial DNA. Neuromuscul. Disord. 1993, 3 , 43-50. [CrossRef]

26. Moraes, C.T.; DiMauro, S.; Zeviani, M.; Lombes, A.; Shanske, S.; Miranda, A.F.; Nakase, H.; Bonilla, E.; Werneck, L.C.; Servidei, S.; et al. Mitochondrial DNA deletions in progressive external ophthalmoplegia and Kearns-Sayre syndrome. N. Engl. J. Med. 1989, 320, 1293-1299. [CrossRef]

27. Van Goethem, G.; Martin, J.J.; van Broeckhoven, C. Progressive external ophthalmoplegia characterized by multiple deletions of mitochondrial DNA: Unraveling the pathogenesis of human mitochondrial DNA instability and the initiation of a genetic classification. Neuromol. Med. 2003, 3, 129-146. [CrossRef]

28. Morris, A.A.; Leonard, J.V.; Brown, G.K.; Bidouki, S.K.; Bindoff, L.A.; Woodward, C.E.; Harding, A.E.; Lake, B.D.; Harding, B.N.; Farrell, M.A.; et al. Deficiency of respiratory chain complex I is a common cause of Leigh disease. Ann. Neurol. 1996, 40, 25-30. [CrossRef] [PubMed]

29. Van den Ouweland, J.M.; Lemkes, H.H.; Ruitenbeek, W.; Sandkuijl, L.A.; de Vijlder, M.F.; Struyvenberg, P.A.; van de Kamp, J.J.; Maassen, J.A. Mutation in mitochondrial tRNA (Leu)(UUR) gene in a large pedigree with maternally transmitted type II diabetes mellitus and deafness. Nat. Genet. 1992, 1, 368-371. [CrossRef]

30. Prezant, T.R.; Agapian, J.V.; Bohlman, M.C.; Bu, X.; Oztas, S.; Qiu, W.Q.; Arnos, K.S.; Cortopassi, G.A.; Jaber, L.; Rotter, J.I.; et al. Mitochondrial ribosomal RNA mutation associated with both antibiotic-induced and non-syndromic deafness. Nat. Genet. 1993, 4, 289-294. [CrossRef] [PubMed]

31. Reid, F.M.; Vernham, G.A.; Jacobs, H.T. A novel mitochondrial point mutation in a maternal pedigree with sensorineural deafness. Hum. Mutat. 1994, 3, 243-247. [CrossRef] [PubMed]

32. Otaegui, D.; Paisán, C.; Sáenz, A.; Martí, I.; Ribate, M.; Martí-Massó, J.F.; Pérez-Tur, J.; López de Munain, A. Mitochondrial polymporphisms in Parkinson's Disease. Neurosci. Lett. 2004, 370, 171-174. [CrossRef]

33. Liu, Y.; Li, R.; Li, Z.; Wang, X.J.; Yang, L.; Wang, S.; Guan, M.X. Mitochondrial transfer RNAMet 4435A $>$ G mutation is associated with maternally inherited hypertension in a Chinese pedigree. Hypertension 2009, 53, 1083-1090. [CrossRef] [PubMed] 
34. Petros, J.A.; Baumann, A.K.; Ruiz-Pesini, E.; Amin, M.B.; Sun, C.Q.; Hall, J.; Lim, S.; Issa, M.M.; Flanders, W.D.; Hosseini, S.H.; et al. mtDNA mutations increase tumorigenicity in prostate cancer. Proc. Natl. Acad. Sci. USA 2005, 102, 719-724. [CrossRef]

35. Andreu, A.L.; Hanna, M.G.; Reichmann, H.; Bruno, C.; Penn, A.S.; Tanji, K.; Pallotti, F.; Iwata, S.; Bonilla, E.; Lach, B.; et al. Exercise intolerance due to mutations in the cytochrome b gene of mitochondrial DNA. N. Engl. J. Med. 1999, 341, $1037-1044$. [CrossRef]

36. Rose, M.R. Mitochondrial myopathies: Genetic mechanisms. Arch. Neurol. 1998, 55, 17-24. [CrossRef]

37. Tarnopolsky, M.A.; Maguire, J.; Myint, T.; Applegarth, D.; Robinson, B.H. Clinical, physiological, and histological features in a kindred with the T3271C melas mutation. Muscle Nerve 1998, 21, 25-33. [CrossRef]

38. Macmillan, C.; Kirkham, T.; Fu, K.; Allison, V.; Andermann, E.; Chitayat, D.; Fortier, D.; Gans, M.; Hare, H.; Quercia, N.; et al. Pedigree analysis of French Canadian families with T14484C Leber's hereditary optic neuropathy. Neurology 1998, 50, 417-422. [CrossRef]

39. Larsson, N.G.; Tulinius, M.H.; Holme, E.; Oldfors, A. Pathogenetic aspects of the A8344G mutation of mitochondrial DNA associated with MERRF syndrome and multiple symmetric lipomas. Muscle Nerve Suppl. 1995, 3, S102-S106. [CrossRef]

40. Carrozzo, R.; Tessa, A.; Vázquez-Memije, M.E.; Piemonte, F.; Patrono, C.; Malandrini, A.; Dionisi-Vici, C.; Vilarinho, L.; Villanova, M.; Schägger, H.; et al. The T9176G mtDNA mutation severely affects ATP production and results in Leigh syndrome. Neurology 2001, 56, 687-690. [CrossRef]

41. Crimi, M.; Papadimitriou, A.; Galbiati, S.; Palamidou, P.; Fortunato, F.; Bordoni, A.; Papandreou, U.; Papadimitriou, D.; Hadjigeorgiou, G.M.; Drogari, E.; et al. A new mitochondrial DNA mutation in ND3 gene causing severe Leigh syndrome with early lethality. Pediatr. Res. 2004, 55, 842-846. [CrossRef] [PubMed]

42. Van Gisbergen, M.W.; Voets, A.M.; Starmans, M.H.; De Coo, I.F.; Yadak, R.; Hoffmann, R.F.; Boutros, P.C.; Smeets, H.J.; Dubois, L.; Lambin, P. How do changes in the mtDNA and mitochondrial dysfunction influence cancer and cancer therapy? Challenges, opportunities and models. Mutat. Res. Rev. Mutat. Res. 2015, 764, 16-30. [CrossRef] [PubMed]

43. Yahata, N.; Matsumoto, Y.; Omi, M.; Yamamoto, N.; Hata, R. TALEN-mediated shift of mitochondrial DNA heteroplasmy in MELAS-iPSCs with m.13513G>A mutation. Sci. Rep. 2017, 7, 15557. [CrossRef] [PubMed]

44. Howell, N.; Herrnstadt, C.; Shults, C.; Mackey, D.A. Low penetrance of the 14484 LHON mutation when it arises in a nonhaplogroup J mtDNA background. Am. J. Med. Genet A 2003, 119A, 147-151. [CrossRef]

45. Tanaka, M.; Gong, J.S.; Zhang, J.; Yoneda, M.; Yagi, K. Mitochondrial genotype associated with longevity. Lancet 1998, 351, 185-186. [CrossRef]

46. Gong, J.-S.; Zhang, J.; Yoneda, M.; Sahashi, K.; Miyajima, H.; Yamauchi, K.; Yagi, K.; Tanaka, M. Mitochondrial Genotype Frequent in Centenarians Predisposes Resistance to Adult-Onset Diseases. J. Clin. Biochem. Nutr. 1998, 24, 105-111. [CrossRef]

47. Kang, D.; Takashige, K.; Sekiguchi, M.; Singh, K.K. Mitochondrial DNA Mutations in aging Disease and Cancer; Springer Nature Switzerland AG: Cham, Switzerland, 1998; Chapter 1; pp. 1-15.

48. Larsson, N.G. Somatic mitochondrial DNA mutations in mammalian aging. Ann. Rev. Biochem. 2010, 79, 683-706. [CrossRef]

49. Kauppila, T.E.S.; Kauppila, J.H.K.; Larsson, N.G. Mammalian Mitochondria and Aging: An Update. Cell Metab. 2017, 25, 57-71. [CrossRef]

50. Seo, A.Y.; Joseph, A.M.; Dutta, D.; Hwang, J.C.; Aris, J.P.; Leeuwenburgh, C. New insights into the role of mitochondria in aging: Mitochondrial dynamics and more. J. Cell Sci. 2010, 123, 2533-2542. [CrossRef]

51. Takagi, K.; Yamada, Y.; Gong, J.S.; Sone, T.; Yokota, M.; Tanaka, M. Association of a 5178C->A (Leu237Met) polymorphism in the mitochondrial DNA with a low prevalence of myocardial infarction in Japanese individuals. Atherosclerosis 2004, 175, 281-286. [CrossRef]

52. Simonetti, S.; Chen, X.; DiMauro, S.; Schon, E.A. Accumulation of deletions in human mitochondrial DNA during normal aging: Analysis by quantitative PCR. Biochim. Biophys. Acta. 1992, 1180, 113-122. [CrossRef]

53. Tseng, L.M.; Yin, P.H.; Chi, C.W.; Hsu, C.Y.; Wu, C.W.; Lee, L.M.; Wei, Y.H.; Lee, H.C. Mitochondrial DNA mutations and mitochondrial DNA depletion in breast cancer. Genes Chromosomes Cancer 2006, 45, 629-638. [CrossRef]

54. Kulkarni, R.; Reither, A.; Thomas, R.A.; Tucker, J.D. Mitochondrial mutant cells are hypersensitive to ionizing radiation, phleomycin and mitomycin C. Mutat. Res. 2009, 663, 46-51. [CrossRef]

55. Mengel-From, J.; Thinggaard, M.; Dalgárd, C.; Kyvik, K.O.; Christensen, K.; Christiansen, L. Mitochondrial DNA copy number in peripheral blood cells declines with age and is associated with general health among elderly. Hum. Genet. 2014, 133, 1149-1159. [CrossRef] [PubMed]

56. Knez, J.; Winckelmans, E.; Plusquin, M.; Thijs, L.; Cauwenberghs, N.; Gu, Y.; Staessen, J.A.; Nawrot, T.S.; Kuznetsova, T. Correlates of peripheral blood mitochondrial DNA content in a general population. Am. J. Epidemiol. 2016, 183, 138-146. [CrossRef]

57. Sondheimer, N.; Glatz, C.E.; Tirone, J.E.; Deardorff, M.A.; Krieger, A.M.; Hakonarson, H. Neutral mitochondrial heteroplasmy and the influence of aging. Hum. Mol. Genet. 2011, 20, 1653-1659. [CrossRef] [PubMed]

58. Li, M.; Rothwell, R.; Vermaat, M.; Wachsmuth, M.; Schroder, R.; Laros, J.F.; van Oven, M.; De Bakker, P.I.; Bovenberg, J.A.; van Duijn, C.M.; et al. Transmission of human mtDNA heteroplasmy in the genome of the Netherlands families: Support for a variable-size bottleneck. Genome Res. 2016, 26, 417-426. [CrossRef] [PubMed]

59. Indo, H.P.; Suenaga, S.; Tomita, K.; Ito, H.; Matsui, H.; Majima, H.J. Analysis of Oxidative Stress Marker, mitochondrial DNA copy numbers and Mitochondrial DNA Oxidation among 135 persons who live in Amami islands, high centenarian population District in Kagoshima. Free Radic. Biol. Med. 2018, 120, S134. [CrossRef] 
60. Sun, X.; Zhan, L.; Chen, Y.; Wang, G.; He, L.; Wang, Q.; Zhou, F.; Yang, F.; Wu, J.; Wu, Y.; et al. Increased mtDNA copy number promotes cancer progression by enhancing mitochondrial oxidative phosphorylation in microsatellite-stable colorectal cancer. Signal. Transduct. Target. Ther. 2018, 3, 8. [CrossRef]

61. Mi, J.; Tian, G.; Liu, S.; Li, X.; Ni, T.; Zhang, L.; Wang, B. The relationship between altered mitochondrial DNA copy number and cancer risk: A meta-analysis. Sci. Rep. 2015, 5, 10039. [CrossRef]

62. Lemnrau, A.; Brook, M.N.; Fletcher, O.; Coulson, P.; Tomczyk, K.; Jones, M.; Ashworth, A.; Swerdlow, A.; Orr, N.; Garcia-Closas, M. Mitochondrial DNA copy number in peripheral blood cells and risk of developing breast cancer. Cancer Res. 2015, 75, 2844-2850. [CrossRef] [PubMed]

63. Shen, J.; Wan, J.; Song, R.; Zhao, H. Peripheral blood mitochondrial DNA copy number, length heteroplasmy and breast cancer risk: A replication study. Carcinogenesis 2015, 36, 1307-1313. [CrossRef] [PubMed]

64. Shen, J.; Gopalakrishnan, V.; Lee, J.E.; Fang, S.; Zhao, H. Mitochondrial DNA copy number in peripheral blood and melanoma risk. PLoS ONE 2015, 10, e0131649. [CrossRef] [PubMed]

65. Hosgood, H.D., 3rd; Liu, C.-S.; Rothman, N.; Weinstein, S.J.; Bonner, M.R.; Shen, M.; Lim, U.; Virtamo, J.; Cheng, W.; Albanes, D.; et al. Mitochondrial DNA copy number and lung cancer risk in a prospective cohort study. Carcinogenesis 2010, 31, 847-849. [CrossRef]

66. Lynch, S.M.; Weinstein, S.J.; Virtamo, J.; Lan, Q.; Liu, C.-S.; Cheng, W.-L.; Rothman, N.; Albanes, D.; Stolzenberg- Solomon, R.Z. Mitochondrial DNA copy number and pancreatic cancer in the Alpha-tocopherol beta- carotene cancer prevention study. Cancer Prev. Res. 2011, 4, 1912-1919. [CrossRef] [PubMed]

67. Xing, J.; Chen, M.; Wood, C.G.; Lin, J.; Spitz, M.R.; Ma, J.; Amos, C.I.; Shields, P.G.; Benowitz, N.L.; Gu, J.; et al. Mitochondrial DNA content: Its genetic heritability and association with renal cell carcinoma. J. Natl. Cancer Inst. 2008, 100, $1104-1112$. [CrossRef]

68. Reznik, E.; Miller, M.L.; Şenbabaoğlu, Y.; Riaz, N.; Sarungbam, J.; Tickoo, S.K.; Al-Ahmadie, H.A.; Lee, W.; Seshan, V.E.; Hakimi, A.A.; et al. Mitochondrial DNA copy number variation across human cancers. eLife 2016, 5, e10769. [CrossRef]

69. Huang, B.; Gao, Y.-T.; Shu, X.-O.; Wen, W.; Yang, G.; Li, G.; Courtney, R.; Ji, B.-T.; Li, H.-L.; Purdue, M.P.; et al. Association of leukocyte mitochondrial DNA copy number with colorectal cancer risk: Results from the Shanghai Women's Health Study. Cancer Epidemiol. Biomark. Prev. 2014, 23, 2357-2365. [CrossRef]

70. King, M.P.; Attardi, G. Human cells lacking mtDNA: Repopulation with exogenous mitochondria by complementation. Science 1989, 246, 500-503. [CrossRef]

71. Park, S.Y.; Chang, I.; Kim, J.Y.; Kang, S.W.; Park, S.H.; Singh, K.; Lee, M.S. Resistance of mitochondrial DNA-depleted cells against cell death: Role of mitochondrial superoxide dismutase. J. Biol. Chem. 2004, 279, 7512-7520. [CrossRef]

72. Ishihara, Y.; Tsuji, M.; Kawamoto, T.; Yamazaki, T. Involvement of reactive ox- ygen species derived from mitochondria in neuronal injury elicited by methylmercury. J. Clin. Biochem. Nutr. 2016, 59, 182-190. [CrossRef]

73. Grant, C.M.; MacIver, F.H.; Dawes, I.W. Mitochondrial function is required for resistance to oxidative stress in the yeast Saccharomyces cerevisiae. FEBS Lett. 1997, 410, 219-222. [CrossRef]

74. Cardoso, S.M.; Rego, A.C.; Penacho, N.; Oliveira, C.R. Apoptotic cell death induced by hydrogen peroxide in NT2 parental and mitochondrial DNA depleted cells. Neurochem. Int. 2004, 45, 693-698. [CrossRef] [PubMed]

75. Tomita, K.; Kuwahara, Y.; Takashi, Y.; Tsukahara, T.; Kurimasa, A.; Fukumoto, M.; Nishitani, Y.; Sato, T. Sensitivity of mitochondrial DNA depleted $\rho^{0}$ cells to $\mathrm{H}_{2} \mathrm{O}_{2}$ depends on the plasma membrane status. Biochem. Biophys. Res. Commun. 2017, 490, 330-335. [CrossRef] [PubMed]

76. Takeshige, K.; Minakami, S. NADH- and NADPH-dependent formation of superoxide anions by bovine heart submitochondrial particles and NADH-ubiquinone reductase preparation. Biochem. J. 1979, 180, 129-135. [CrossRef] [PubMed]

77. Boveris, A.; Chance, B. The mitochondrial generation of hydrogen peroxide. General properties and effect of hyperbaric oxygen. Biochem. J. 1973, 134, 707-716. [CrossRef]

78. Takayanagi, R.; Takeshige, K.; Minakami, S. NADH- and NADPH-dependent lipid peroxidation in bovine heart submitochondrial particles. Dependence on the rate of electron flow in the respiratory chain and an antioxidant role of ubiquinol. Biochem. J. 1980, 192, 853-860. [CrossRef]

79. Zamzami, N.; Marchetti, P.; Castedo, M.; Zanin, C.; Vayssière, J.L.; Petit, P.X.; Kroemer, G. Reduction in mitochondrial potential constitutes an early irreversible step of programmed lymphocyte death in vivo. J. Exp. Med. 1995, 181, 1661-1672. [CrossRef]

80. Warburg, O. On the origin of cancer cells. Science 1956, 123, 309-314. [CrossRef]

81. Samudio, I.; Fiegl, M.; Andreeff, M. Mitochondrial uncoupling and the Warburg effect: Molecular basis for the reprogramming of cancer cell metabolism. Cancer Res. 2009, 69, 2163-2166. [CrossRef] [PubMed]

82. Ott, M.; Gogvadze, V.; Orrenius, S.; Zhivotovsky, B. Mitochondria, oxidative stress and cell death. Apoptosis 2007, 12, 913-922. [CrossRef]

83. Kinnally, K.W.; Peixoto, P.M.; Ryu, S.Y.; Dejean, L.M. Is mPTP the gatekeeper for necrosis, apoptosis, or both? Biochim. Biophys. Acta 2011, 1813, 616-622. [CrossRef]

84. Elliott, R.L.; Jiang, X.P.; Head, J.F. Mitochondrial organelle transplantation: Introduction of normal epithelial mitochondria into human cancer cells inhibits proliferation and increases drug sensitivity. Breast Cancer Res. Treat. 2012, 136, 347. [CrossRef] [PubMed] 
85. Emani, S.M.; Piekarski, B.L.; Harrild, D.; Del Nido, P.J.; McCully, J.D. Autologous mitochondrial transplantation for dysfunction after ischemia-reperfusion injury. J. Thorac. Cardiovasc. Surg. 2017, 154, 286-289. [CrossRef] [PubMed]

86. Spees, J.L.; Olson, S.D.; Whitney, M.J.; Prockop, D.J. Mitochondrial transfer between cells can rescue aerobic respiration. Proc. Natl. Acad. Sci. USA 2006, 103, 1283-1288. [CrossRef] [PubMed]

87. Ahmad, T.; Mukherjee, S.; Pattnaik, B.; Kumar, M.; Singh, S.; Kumar, M.; Rehman, R.; Tiwari, B.K.; Jha, K.A.; Barhanpurkar, A.P.; et al. Miro1 regulates intercellular mitochondrial transport \& enhances mesenchymal stem cell rescue efficacy. EMBO J. 2014, 33, 994-1010. [PubMed]

88. Rustom, A.; Saffrich, R.; Markovic, I.; Walther, P.; Gerdes, H.H. Nanotubular highways for intercellular organelle transport. Science 2004, 303, 1007-1010. [CrossRef] [PubMed]

89. Tachibana, M.; Sparman, M.; Sritanaudomchai, H.; Ma, H.; Clepper, L.; Woodward, J.; Li, Y.; Ramsey, C.; Kolotushkina, O.; Mitalipov, S. Mitochondrial gene replacement in primate offspring and embryonic stem cells. Nature 2009, 461,367-372. [CrossRef]

90. Craven, L.; Tuppen, H.A.; Greggains, G.D.; Harbottle, S.J.; Murphy, J.L.; Cree, L.M.; Murdoch, A.P.; Chinnery, P.F.; Taylor, R.W.; Lightowlers, R.N.; et al. Pronuclear transfer in human embryos to prevent transmission of mitochondrial DNA disease. Nature 2010, 465, 82-85. [CrossRef]

91. Hyslop, L.A.; Blakeley, P.; Craven, L.; Richardson, J.; Fogarty, N.M.; Fragouli, E.; Lamb, M.; Wamaitha, S.E.; Prathalingam, N.; Zhang, Q.; et al. Towards clinical application of pronuclear transfer to prevent mitochondrial DNA disease. Nature 2016, 534, 383-386. [CrossRef]

92. Jabbari, H.; Roushandeh, A.M.; Rostami, M.K.; Razavi-Toosi, M.T.; Shokrgozar, M.A.; Jahanian-Najafabadi, A.; Kuwahara, Y.; Roudkenar, M.H. Mitochondrial transplantation ameliorates ischemia/reperfusion-induced kidney injury in rat. Biochim. Biophys. Acta (BBA) 2020, 1866, 165809. [CrossRef]

93. Roushandeh, A.M.; Kuwahara, Y.; Roudkenar, M.H. Mitochondrial transplantation as a potential and novel master key for treatment of various incurable diseases. Cytotechnology 2019, 71, 647-663. [CrossRef]

94. Pourmohammadi-Bejarpasi, Z.; Roushandeh, A.M.; Saberi, A.; Kheirandish-Rostami, M.; Toosi, S.M.R.; Jahanian-Najafabadi, A.; Tomita, K.; Kuwahara, Y.; Sato, T.; Roudkenar, M.H. Mesenchymal stem cells-derived mitochondria transplantation mitigates I/R-induced injury, abolishes I/R-induced apoptosis, and restores motor function in acute ischemia stroke rat model. Brain Res. Bull. 2020, 165, 70-80. [CrossRef] [PubMed]

95. Roushandeh, A.M.; Tomita, K.; Kuwahara, Y.; Jahanian-Najafabadi, A.; Igarashi, K.; Roudkenar, M.H.; Sato, T. Transfer of healthy fibroblast-derived mitochondria to HeLa $\rho^{0}$ and SAS $\rho^{0}$ cells recovers the proliferation capabilities of these cancer cells under conventional culture medium but increase their sensitivity to cisplatin-induced apoptotic death. Mol. Biol. Rep. 2020, 47, 4401-4411. [CrossRef] [PubMed]

96. Kheirandish-Rostami, M.; Roudkenar, M.H.; Jahanian-Najafabadi, A.; Tomita, K.; Kuwahara, Y.; Sato, T.; Roushandeh, A.M. Mitochondrial characteristics contribute to proliferation and migration potency of MDA-MB-231 cancer cells and their response to cisplatin treatment. Life Sci. 2020, 244, 117339. [CrossRef] [PubMed]

97. Takashi, Y.; Tomita, K.; Kuwahara, Y.; Roudkenar, M.H.; Roushandeh, A.M.; Igarashi, K.; Nagasawa, T.; Nishitani, Y.; Sato, T. Mitochondrial dysfunction promotes aquaporin expression that controls hydrogen peroxide permeability and ferroptosis. Free Radic. Biol. Med. 2020, 161, 60-70. [CrossRef]

98. Guariento, A.; Doulamis, I.P.; Duignan, T.; Kido, T.; Regan, W.L.; Saeed, M.Y.; Hoganson, D.M.; Emani, S.M.; Fynn-Thompson, F.; Matte, G.S.; et al. Mitochondrial transplantation for myocardial protection in ex-situ-perfused hearts donated after circulatory death. J. Heart Lung Transplant. 2020, 2498, 31625-31629. [CrossRef]

99. McCully, J.D.; Levitsky, S.; Del Nido, P.J.; Cowan, D.B. Mitochondrial transplantation for therapeutic use. Clin. Transl. Med. 2016, 5, 16. [CrossRef]

100. Callaway, E. UK sets sights on gene therapy in eggs. Nature 2012, 481, 419. [CrossRef]

101. Kong, L.H.; Liu, Z.; Li, H.; Zhu, L.; Chen, S.L.; Xing, F.Q. First twins born in Mainland China by autologous granular cell mitochondria transfer. Acad. J. First Med. Coll. PLA 2003, 23, 990-991.

102. Shin, B.; Cowan, D.B.; Emani, S.M.; Del Nido, P.J.; McCully, J.D. Mitochondrial Transplantation in Myocardial Ischemia and Reperfusion Injury. Adv. Exp. Med. Biol. 2017, 982, 595-619.

103. Chang, J.C.; Chang, H.S.; Wu, Y.C.; Cheng, W.L.; Lin, T.T.; Chang, H.J.; Kuo, S.J.; Chen, S.T.; Liu, C.S. Mitochondrial transplantation regulates antitumour activity, chemoresistance and mitochondrial dynamics in breast cancer. J. Exp. Clin. Cancer Res. 2019, 38, 30. [CrossRef]

104. Hayakawa, K.; Esposito, E.; Wang, X.; Terasaki, Y.; Liu, Y.; Xing, C.; Ji, X.; Lo, E.H. Transfer of mitochondria from astrocytes to neurons after stroke. Nature 2016, 535, 551-555. [CrossRef]

105. Nitzan, K.; Benhamron, S.; Valitsky, M.; Kesner, E.E.; Lichtenstein, M.; Ben-Zvi, A.; Ella, E.; Segalstein, Y.; Saada, A.; LorberboumGalski, H.; et al. Mitochondrial Transfer Ameliorates Cognitive Deficits, Neuronal Loss, and Gliosis in Alzheimer's Disease Mice. J. Alzheimer's Dis. 2019, 72, 587-604. [CrossRef] [PubMed]

106. Chang, J.C.; Wu, S.L.; Liu, K.H.; Chen, Y.H.; Chuang, C.S.; Cheng, F.C.; Su, H.L.; Wei, Y.H.; Kuo, S.J.; Liu, C.S. Allogeneic/xenogeneic transplantation of peptide-labeled mitochondria in Parkinson's disease: Restoration of mitochondria functions and attenuation of 6-hydroxydopamine-induced neurotoxicity. Transl. Res. 2016, 170, 40-56. [CrossRef] 
107. Kuo, C.C.; Su, H.L.; Chang, T.L.; Chiang, C.Y.; Sheu, M.L.; Cheng, F.C.; Chen, C.J.; Sheehan, J.; Pan, H.C. Prevention of Axonal Degeneration by Perineurium Injection of Mitochondria in a Sciatic Nerve Crush Injury Model. Neurosurgery 2017, 80, 475-488. [CrossRef]

108. Woods, D.C.; Tilly, J.L. Autologous Germline Mitochondrial Energy Transfer (AUGMENT) in human assisted reproduction. Semin. Reprod. Med. 2015, 33, 410-421. [CrossRef] [PubMed]

109. Gao, J.; Qin, A.; Liu, D.; Ruan, R.; Wang, Q.; Yuan, J.; Cheng, T.S.; Filipovska, A.; Papadimitriou, J.M.; Dai, K.; et al. Endoplasmic reticulum mediates mitochondrial transfer within the osteocyte dendritic network. Sci. Adv. 2019, 5, eaaw7215. [CrossRef] [PubMed]

110. Kuwahara, Y.; Li, L.; Baba, T.; Nakagawa, H.; Shimura, T.; Yamamoto, Y.; Ohkubo, Y.; Fukumoto, M. Clinically relevant radioresistant cells efficiently repair DNA double-strand breaks induced by X-rays. Cancer Sci. 2009, 100, 747-752. [CrossRef] [PubMed]

111. Kuwahara, Y.; Mori, M.; Oikawa, T.; Shimura, T.; Ohtake, Y.; Mori, S.; Ohkubo, Y.; Fukumoto, M. The modified high-density survival assay is the useful tool to predict the effectiveness of fractionated radiation exposure. J. Radiat. Res. 2010, 51, 297-302. [CrossRef]

112. Kuwahara, Y.; Mori, M.; Kitahara, S.; Fukumoto, M.; Ezaki, T.; Mori, S.; Echigo, S.; Ohkubo, Y.; Fukumoto, M. Targeting of tumor endothelial cells combining $2 \mathrm{~Gy} /$ day of X-ray with Everolimus is the effective modality for overcoming clinically relevant radioresistant tumors. Cancer Med. 2014, 3, 310-321. [CrossRef]

113. Kuwahara, Y.; Roudkenar, M.H.; Urushihara, Y.; Saito, Y.; Tomita, K.; Roushandeh, A.M.; Sato, T.; Kurimasa, A.; Fukumoto, M. Clinically relevant radioresistant cells: A simple model to understand cancer radioresistance. Med. Mol. Morphol. 2017, 50, 195-204. [CrossRef] [PubMed]

114. Tomita, K.; Kuwahara, Y.; Takashi, Y.; Igarashi, K.; Nagasawa, T.; Nabika, H.; Kurimasa, A.; Fukumoto, M.; Nishitani, Y.; Sato, T. Clinically Relevant Radioresistant Cells Exhibit Resistance to $\mathrm{H}_{2} \mathrm{O}_{2}$ by Decreasing Internal $\mathrm{H}_{2} \mathrm{O}_{2}$ and Lipid Peroxidation. Tumor Biol. 2018, 40, 1-11. [CrossRef] [PubMed]

115. Pallast, S.; Arai, K.; Wang, X.; Lo, E.H.; van Leyen, K. 12/15-Lipoxygenase targets neuronal mitochondria under oxidative stress. J. Neurochem. 2009, 111, 882-889. [CrossRef]

116. Tomita, K.; Nagasawa, T.; Kuwahara, Y.; Torii, S.; Igarashi, K.; Roudkenar, M.H.; Roushandeh, A.M.; Kurimasa, A.; Sato, T. MiR-7-5p Is Involved in Ferroptosis Signaling and Radioresistance Thru the Generation of ROS in Radioresistant HeLa and SAS Cell Lines. Int. J. Mol. Sci. 2021, 22, 8300. [CrossRef] [PubMed]

117. Kuwahara, Y.; Tomita, K.; Roudkenar, M.H.; Roushandeh, A.M.; Urushihara, Y.; Igarashi, K.; Nagasawa, T.; Kurimasa, A.; Fukumoto, M.; Sato, T. The Effects of Hydrogen Peroxide and/or Radiation on the Survival of Clinically Relevant Radioresistant Cells. Technol Cancer Res. Treat. 2020, 19, 1533033820980077. [CrossRef] [PubMed]

118. Kuwahara, Y.; Roudkenar, M.H.; Suzuki, M.; Urushihara, Y.; Fukumoto, M.; Saito, Y.; Fukumoto, M. The involvement of mitochondrial membrane potential in cross-resistance between radiation and docetaxel. Int. J. Radiat. Oncol. Biol. Phys. 2016, 96, 556-565. [CrossRef]

119. Tomita, K.; Fukumoto, M.; Itoh, K.; Kuwahara, Y.; Igarashi, K.; Nagasawa, T.; Suzuki, M.; Kurimasa, A.; Sato, T. MiR-7-5p is a key factor that controls radioresistance via intracellular $\mathrm{Fe}^{2+}$ content in clinically relevant radioresistant cells. Biochem. Biophys. Res. Commun. 2019, 518, 712-718. [CrossRef]

120. Fukumoto, M.; Amanuma, T.; Kuwahara, Y.; Shimura, T.; Suzuki, M.; Mori, S.; Kumamoto, H.; Saito, Y.; Ohkubo, Y.; Duan, Z.; et al. Guanine nucleotide-binding protein 1 is one of the key molecules contributing to cancer cell radioresistance. Cancer Sci. 2014, 105, 1351-1359. [CrossRef]

121. Qiu, X.; Guo, H.; Yang, J.; Ji, Y.; Wu, C.S.; Chen, X. Down-regulation of guanylate binding protein 1 causes mitochondrial dysfunction and cellular senescence in macrophages. Sci. Rep. 2018, 8, 1679. [CrossRef]

122. Kuwahara, Y.; Oikawa, T.; Ochiai, Y.; Roudkenar, M.H.; Fukumoto, M.; Shimura, T.; Ohtake, Y.; Ohkubo, Y.; Mori, S.; Uchiyama, Y.; et al. Enhancement of autophagy is a potential modality for tumors refractory to radiotherapy. Cell Death Dis. 2011, 2, e177. [CrossRef] [PubMed]

123. Morita, M.; Prudent, J.; Basu, K.; Goyon, V.; Katsumura, S.; Hulea, L.; Pearl, D.; Siddiqui, N.; Strack, S.; McGuirk, S.; et al. mTOR Controls Mitochondrial Dynamics and Cell Survival via MTFP1. Mol. Cell 2017, 67, 922-935. [CrossRef]

124. Takashi, Y.; Tomita, K.; Kuwahara, Y.; Nabika, H.; Igarashi, K.; Nagasawa, T.; Kurimasa, A.; Fukumoto, M.; Nishitani, Y.; Sato, T. Data on the aquaporin gene expression differences among $\rho^{0}$, clinically relevant radioresistant, and the parental cells of human cervical cancer and human tongue squamous cell carcinoma. Data Brief. 2018, 20, 402-410. [CrossRef] [PubMed]

125. Petragnano, F.; Pietrantoni, I.; Camero, S.; Codenotti, S.; Milazzo, L.; Vulcano, F.; Macioce, G.; Giordani, I.; Tini, P.; Cheleschi, S.; et al. Clinically relevant radioresistant rhabdomyosarcoma cell lines: Functional, molecular and immune-related characterization. J. Biomed. Sci. 2020, 27, 90. [CrossRef] [PubMed] 